\title{
Fungal Endophytes from Three Cultivars of Panax ginseng Meyer Cultivated in Korea
}

\author{
Sang Un Park ${ }^{1}$, Hyoun-Sub Lim², Kee-Choon Park ${ }^{3}$, Young-Hwan Park ${ }^{4}$, and Hanhong Bae ${ }^{4 *}$ \\ ${ }^{1}$ Department of Crop Science, Chungnam National University, Daejeon 305-754, Korea \\ ${ }^{2}$ Department of Applied Microbiology, Chungnam National University, Daejeon 305-764, Korea \\ ${ }^{3}$ National Institute of Horticultural \& Herbal Science, Rural Development Administration, Eumseong 369-873, Korea \\ ${ }^{4}$ School of Biotechnology, Yeungnam University, Gyeongsan 712-749, Korea
}

In order to investigate the diversity of endophytes, fungal endophytes in Panax ginseng Meyer cultivated in Korea were isolated and identified using internal transcribed spacer (ITS) sequences of ribosomal DNA. Three cultivars of 3-year-old ginseng roots (Chunpoong, Yunpoong, and Gumpoong) were used to isolate fungal endophytes. Surface sterilized ginseng roots were placed on potato dextrose agar plates supplemented with ampicilin and streptomycin to inhibit bacterial growth. Overall, 38 fungal endophytes were isolated from 12 ginseng roots. According to the sequence analysis of the ITS1-5.8S-ITS2, 38 fungal isolates were classified into 4 different fungal species, which were Phoma radicina, Fusarium oxysporum, Setophoma terrestris and Ascomycota sp. 2-RNK. The most dominant fungal endophyte was $P$. radicina in 3 cultivars. The percentage of dominant endophytes of $P$. radicina was $65.8 \%$. The percentage of colonization frequency of $P$. radicina was $80 \%, 52.9 \%$, and $75 \%$ in Chunpoong, Yunpoong, and Gumpoong, respectively. The second most dominant fungal endophyte was $F$. oxysporum. The diversity of the fungal endophytes was low and no ginseng cultivar specificity among endophytes was detected in this study. The identified endophytes can be potential fungi for the production of bioactive compounds and control against ginseng pathogens.

Keywords: Panax ginseng, Fungal endophytes, Internal transcribed spacer (ITS) sequence

\section{INTRODUCTION}

Ginseng (Panax ginseng Meyer) is the most valuable traditional herb. Ginseng has well-known, diverse actions and effects on the human body, such as nonspecific resistance to biochemical and physical stresses, and the improvement of vitality, longevity and mental capacity [1-6]. Generally 4 to 6 years of growth are required to produce high quality ginseng roots and the cultivation of ginseng should be under shade conditions. Consecutive cultivation in the same soil causes severe reduction in production mainly due to pathogenic infection [7]. Heavy use of chemical pesticides has been applied to ginseng fields to

(cc) This is an Open Access article distributed under the terms of the Creative Commons Attribution Non-Commercial License (http://creativecommons.org/licenses/by-nc/3.0/) which permits unrestricted non-commercial use, distribution, and reproduction in any medium, provided the original work is properly cited. control pathogens, which results in the contamination of ginseng roots and the surrounding soil. The importance of biological control methods is now widely recognized to produce organic ginseng roots and reduce environmental contamination.

De Barry [8] first used the term 'endophyte' to describe microbes that reside inside the living tissues of healthy plants. Endophytes were subsequently described as fungi and bacteria that spend the most or part of their life cycle internally and asymptomatically in the healthy living tissues of plants $[9,10]$. It is believed that fungal endophytes

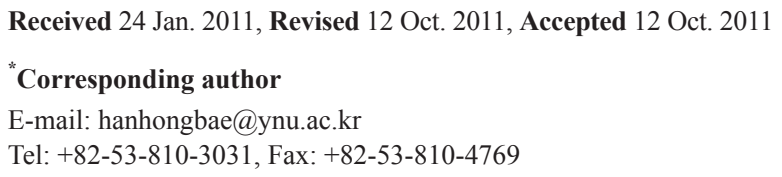


originated from pathogenic fungi which either lost their virulence or exhibit extended latent periods [11,12]. Fungal endophytes colonize either locally or systemically in inter- or intra-cellular locations [13]. Many studies have shown that fungal endophytes are ubiquitous in most plants and colonize without apparent harm to their hosts [14]. However, fungal endophytes could be pathogenic to other species $[13,15]$. Various relationship between fungal endophytes and plants has been observed, which ranges from mutualistic or symbiotic to antagonistic or pathogenic $[13,16]$. There are at least one million estimated species of fungal endophytes in plants [17] as well as in lichens [14]. Most fungal endophytes belong to the Ascomycota clade and some of them belong to the Basidiomycota [18]. Rodriguez et al. [19] identified four classes of fungal endophytes based on host range, colonization pattern, transmission, and ecological function. The function of fungal endophytes might be dependent upon the plant organ-fungus interaction in each plant $[20,21]$. Beneficial endophytes have several positive effects on plants, including growth, nutrient uptake, and tolerance to abiotic and biotic stresses [22].

Recent studies have shed light on the isolation of fungal endophytes from medicinal plants [23,24]. Medicinal plants produce chemicals that can be used as raw material for pharmaceutical, cosmetic, and fragrance industries [25]. Some fungal endophytes produce secondary metabolites that are potential sources for natural products with unique structures and bioactivities [26]. Endophytes in medicinal plants may be involved in the metabolic pathways of medicinal plants and produce analogous or novel bioactive metabolites (e.g., taxol) [27]. Fungal endophytes produce metabolites with potential use for medicinal, agricultural and industrial purposes, such as antibiotics, antimycotics, immuno suppressants, and anticancer compounds [28-31]. In addition, fungi have advantages over plants, such as short cultivation time and large biomass production. However, there are very few reports on fungal endophytes in ginseng [32-34]. Therefore, an extensive investigation of fungal endophytes in ginseng can increase the opportunities of identifying potential fungi that can be used to produce bioactive compounds and control against pathogens. This study has been undertaken to study the diversity of fungal endophytes in three cultivars of Panax ginseng Meyer cultivated in Korea.

\section{MATERIALS AND METHODS}

\section{Collection of ginseng roots}

Three-year-old roots of ginseng, P. ginseng Meyer, were harvested from Gangwon Province, Korea during sunny days in August 2010. Four roots of each cultivar (Chunpoong, Yunpoong, and Gumpoong; 12 roots in total) were harvested, and these were stored at $4^{\circ} \mathrm{C}$ before being processed.

\section{Isolation of fungal endophytes}

Fungal endophytes from ginseng roots were isolated according to Xing et al. [33] with modification. Root samples were thoroughly washed with running tap water and cut into $1 \mathrm{~cm}$ long segments with a clean razor blade. The root segments were surface sterilized with $75 \%$ ethanol for $1 \mathrm{~min}, 4 \% \mathrm{NaHCO}_{3}$ for $3 \mathrm{~min}$, and $75 \%$ ethanol for $30 \mathrm{~s}$. The root segments were rinsed three times with sterile distilled water and blotted with sterile tissue paper. Three aliquots of $0.1 \mathrm{~mL}$ of the water used for the last washing step were inoculated on potato dextrose agar (PDA) plates with $200 \mu \mathrm{g} / \mathrm{mL}$ ampicillin and $200 \mu \mathrm{g} /$ $\mathrm{mL}$ streptomycin to ensure the elimination of ephiphytic microorganisms. The sterilized root segments were transferred to PDA plates amended with ampicillin and streptomycin. PDA plates were incubated at room temperature and checked every day to detect mycelial growth out of the roots. The fungal mycelial tips of the emerging mycelia from the edges of the root segments were transferred to new PDA plates supplemented with ampicillin and streptomycin. The transfer of emerging mycelia from the root segments was continued for up to $4 \mathrm{wk}$.

\section{Identification of fungal isolates}

Mycelia were scraped using a sterile scalpel from 1or 2-week-old PDA fungal cultures. The harvested fungal mycelia were frozen in liquid nitrogen and stored at $-80^{\circ} \mathrm{C}$ until use. Mycelia were ground to a fine powder using a mortar and pestle in liquid nitrogen with sea sand. DNA was extracted using DNeasy Plant Mini kit (Qiagen, CA, USA) according to manufacturer's recommendation. Amplification of the internal transcribed spacer (ITS) region was carried out using the universal eukaryotic primers of ITS1 (5' TCCGTAGGTGAA CCTGCGG 3') and ITS4 (5' TCCTCCGCTTATTGATATGC 3') [32]. PCR was performed in $50 \mu \mathrm{L}$ reaction containing 0.5 $\mu \mathrm{g}$ of DNA, 25 pmol of each primer with the following reaction conditions: $2 \mathrm{~min}$ initial denaturing step at $95^{\circ} \mathrm{C}$, followed by 30 cycles of $1 \mathrm{~min}$ denaturation at $95^{\circ} \mathrm{C}, 1$ min primer annealing at $55^{\circ} \mathrm{C}, 1 \mathrm{~min}$ extension at $72^{\circ} \mathrm{C}$, and a final $5 \mathrm{~min}$ extension at $72^{\circ} \mathrm{C}$. PCR products were analyzed by electrophoresis in $0.8 \%$ agarose gel and the PCR products (approximately $550 \mathrm{bp}$ ) were excised from the gel. DNA was purified using Wizard SV gel and PCR 
Clean-up System (Promega, WI, USA). After sequence analysis, ITS sequences were searched using the NCBI BLAST program (http://www.ncbi.nlm.nih.gov).

Morphological identification was also carried out to confirm the results of molecular identification based on macroscopic and microscopic appearances. The percentage of colonization frequency $(\% \mathrm{CF})$ of fungal endophytes was calculated based on previous studies $[35,36]$ as follows: $\% \mathrm{CF}=\left(N_{\mathrm{COL}} / N t\right) \times 100$, where $N_{\mathrm{COL}}=$ number of segments colonized by each fungus; $N t=$ total number of segments.

\section{Phylogenetic analysis}

A phylogenetic tree was constructed from ITS1-5.8SITS2 sequences by the Maximum Parsimony method and Mega5 software (http://www.megasoftware.net) [37,38]. The Maximum Parsimony tree was generated using the Close-Neighbor-Interchange algorithm [39]. Sclerotinia sclerotiorum was used as an outgroup fungal taxon.

\section{RESULTS AND DISCUSSION}

Total of 38 fungal endophytes were isolated from 12 ginseng roots (184 segments) of 3 cultivars. These were classified into 4 taxonomic species of Ascomycota (Table 1 and Fig. 1). Chunpoong (56 root segments), Yunpoong
(74 segments), and Gumpoong (54 segments) were colonized by 5,17 , and 16 fungal isolates, respectively. Only 5 fungal isolates were identified in Chunpoong, which may be due to the contamination or outgrowth of endophytic bacteria. Bacterial growth usually inhibited the outcome of fungal endophytes due to the fast colonization of root segments, even on PDA plates containing antibiotics.

The analyses of ITS1-5.8S-ITS2 regions showed $100 \%$ identities of Phoma radicina (FJ427058), Fusarium oxysporum (HQ328030), Setophoma terrestris (JN615482: synonym Phoma trrestris, Pyrenochaeta terrestris) and Ascomycota sp. 2-RNK (EU780424) (Table 1). The highest $\mathrm{CF}$ varied among cultivars from $9.4 \%$ to $30.6 \%$ and the average $\mathrm{CF}$ was $21.5 \%$ (Table 1 ), which may also be due to bacterial contamination or growth of bacterial endophytes. Phoma radicina was the most frequent fungal endophyte in three ginseng cultivars: $80 \%, 52.9 \%$, and $75 \%$ of CF in Chunpoong, Yunpoong, and Gumpoong, respectively. In total, the percentage of dominant endophytes (DE) of P. radician was $65.8 \%$, which is the highest percentage among the detected fungal isolates. The second most dominant species was F. oxysporum: $20 \%, 23.5 \%$, and $18.7 \%$ of DE in Chunpoong, Yunpoong, and Gumpoong, respectively. The remaining fungal endophytes isolated were $\mathrm{S}$. terrestris and

Table 1. Fungal endophytes isolated from 3-year-old ginseng roots of 3 cultivars in Gangwon province in Korea

\begin{tabular}{|c|c|c|c|c|c|c|c|}
\hline $\begin{array}{l}\text { Endophytic fungi } \\
\text { cultivar }\end{array}$ & $\begin{array}{c}\text { Phoma radicina } \\
\text { FJ427058 }\end{array}$ & $\begin{array}{c}\text { Fusarium oxysporum } \\
\text { HQ328030 }\end{array}$ & $\begin{array}{c}\text { Setophoma terrestris } \\
\text { JN615482 }\end{array}$ & $\begin{array}{c}\text { Ascomycota sp. } \\
\text { 2-RNK EU780424 }\end{array}$ & $\begin{array}{l}\text { Isolate no. } \\
\text { in total }\end{array}$ & $\mathrm{CF}(\%)$ & Average of $\mathrm{CF}(\%)$ \\
\hline Chunpoong 1 & 1 & & & & 1 & 6.7 & \\
\hline Chunpoong 2 & & & & & 0 & 0.0 & \\
\hline Chunpoong 3 & 2 & & & & 2 & 15.4 & \\
\hline Chunpoong 4 & 1 & 1 & & & 2 & 15.4 & \\
\hline $\mathrm{DE}(\%)$ & 80 & 20 & 0 & 0 & 100 & & 9.4 \\
\hline Yunpoong 1 & 5 & & 1 & & 6 & 46.2 & \\
\hline Yunpoong 2 & & 3 & 2 & & 5 & 20.8 & \\
\hline Yunpoong 3 & 3 & & & 1 & 4 & 19.0 & \\
\hline Yunpoong 4 & 1 & 1 & & & 2 & 12.5 & \\
\hline DE (\%) & 52.9 & 23.6 & 17.6 & 5.9 & 100 & & 24.6 \\
\hline Gumpoong 1 & 2 & & & & 2 & 28.6 & \\
\hline Gumpoong 2 & 5 & & & 1 & 6 & 46.2 & \\
\hline Gumpoong 3 & 4 & 1 & & & 5 & 22.7 & \\
\hline Gumpoong 4 & 1 & 2 & & & 3 & 25 & \\
\hline DE (\%) & 75 & 18.7 & 0.0 & 6.3 & 100 & & 30.6 \\
\hline Isolate no. in total & 25 & 8 & 3 & 2 & 38 & & \\
\hline $\mathrm{DE}(\%)$ in total & 65.8 & 21.0 & 7.9 & 5.3 & 100 & & 21.5 \\
\hline
\end{tabular}

Four roots of each cultivar were used to isolate fungal endophytes (12 roots in total).

$\mathrm{CF}$, colonization frequency; $\mathrm{DE}$, dominant endophyte. 
Ascomycota sp. 2-RNK and \%CF were $7.9 \%$ and $5.3 \%$ in average, respectively.

The number of fungal endophytes found in this study is lower than expected compared with other studies [24,33,40,41]. However, Dang et al. [34] only reported one fungal isolate (Trichoderma ovalisporum) in P. ginseng. This result indicates that distribution of endophytes depends on plant species and geological locations. As mentioned earlier, there are only a limited number of studies reported on the isolation of fungal endophytes in ginseng species. Xing et al. [33] reported 134 fungal isolates with 27 taxa in American ginseng (P. quinquefolium), in which 11 species were identified in detail. Four species (Alternaria, Collectotrichum, Phoma, and Xylariale) were the most common in 3 different tissues (root, stem and leaf) of American ginseng. These genera are known as common endophytes [23,42-44]. Xing et al. [33] reported tissue specificity for the reported endo-

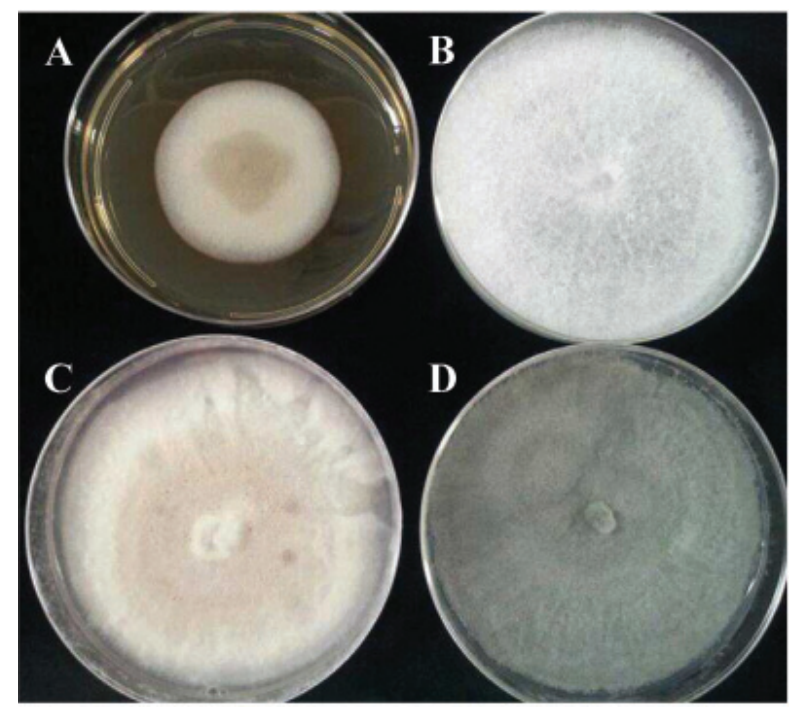

Fig. 1. Endophytic fungi isolated from ginseng roots cultivated in Korea. Fungal isolates were cultivated in potato dextrose agar media for $5 \mathrm{~d}$ at $22^{\circ} \mathrm{C}$. (A) Phoma radicina, (B) Fusarium oxysporum, (C) Setophoma terrestris, and (D) Ascomycota sp. 2-RNK. phytes; Cladosporium sp. were the dominant isolates in roots, but were not detected in stem or leaf tissues. In addition, Cladosporium sp. was not detected in 4-year-old American ginseng roots, but Glomerella cingulata was the dominant species instead. However, we did not find Cladosporium sp. in ginseng roots. They also found that the diversity of fungal endophytes in American ginseng roots decreased with age. This may be because of autotoxic or host defense compounds of American ginseng in the rhizosphere $[33,45,46]$. It has been known that host defense compounds control endophytic communities [47].

The genus, Phoma sp., which was the most dominant isolate in ginseng, was detected only in leaf tissues of 1-, 2- and 3-year-old American ginseng, but not in 4-year old ginseng. Tissue specificity of endophytes has also been reported in previous studies [48-50]. F. oxysporum was the second dominant isolate in ginseng, while it was only detected in 3-year old roots of American ginseng. The genus Phoma is ubiquitously present in the environment and considered an important fungal plant pathogen [51]. In other plant species, Fusarium and Phoma were the most frequent genera among 142 fungal species isolated in roots of 24 plant species growing at 12 sites in Spain [52]. The genera of Fusarium and Phoma have been known as common endophytes in other studies $[13,53,54]$. Aveskamp et al. [51] concluded that endophytic communities were dependent on the soil type and plant species, but not on location. The physio-chemical nature of a soil may influence on the colonization of fungal species to plants. While $F$. oxysporum is commonly present in legume species as a pathogen [55], this fungus can colonize other plants without causing symptoms $[54,56]$. In general, nonpathogenic endophytes can turn into pathogenic strains after introduction into potentially new host plants [56]. We isolated the unclassified Ascomycota sp. 2-RNK that was also isolated from the roots and fruits of neem tree (Azadirachta indica A. Juss.) [57].



Fig. 2. Phylogenetic analysis of fungal endophytes from Panax ginseng Meyer. The phylogenetic tree was constructed from internal transcribed spacer (ITS)1-5.8S-ITS2 sequences using the maximum parsimony method on Mega5 software. The percentage of replicate trees in which the associated taxa clustered together in the bootstrap test (1,000 replicates) is shown next to the branches. GenBank accession numbers are as follows: Phoma radicina (FJ427058), Setophoma terrestris (JN615482), Fusarium oxysporum (HQ328030) and Ascomycota sp. 2-RNK (EU780424). Sclerotinia sclerotiorum (AB607227) was used as outgroup fungal taxa. 
S. terrestris was isolated in ginseng root. Gorenz et al. [58] isolated Pyrenochaeta terrestris as a causal agent of pink root in onions. Fig. 2 shows the maximum parsimony tree grouping fungal endophytes into two clades: 1) $P$. radicina and S. terrestris, and 2) $F$. oxysporum and Ascomycota sp. 2-RNK.

We isolated a limited number of fungal endophytes in ginseng root, but our findings can increase the potential use and awareness of fungal endophytes for beneficial applications. There are very few reports on the diversity of fungal endophytes in ginseng. Therefore, our finding can increase the possibilities of identifying potential fungi that can be used to protect ginseng plants and produce bioactive compounds.

\section{ACKNOWLEDGEMENTS}

We thank Dr. Lee (Andong University, Andong, Korea) for assistance in morphologically identifying fungal endophytes. This research was supported by the Yeungnam University Research Grant in 209-A-356-011.

\section{REFERENCES}

1. Ernst E. Panax ginseng: an overview of the clinical evidence. J Ginseng Res 2010;34:259-263.

2. Lee ST, Chu K, Kim JM, Park HJ, Kim MH. Cognitive improvement by ginseng in Alzheimer's disease. J Ginseng Res 2007;31:51-53.

3. Rausch WD, Weiming L, Gille G, Radad K. Perspectives for ginsenosides in models of Parkinson's disease. J Ginseng Res 2007;31:127-136.

4. Vuksan V, Sievenpipper J, Jovanovski E, Jenkins AL. Current clinical evidence for Korean red ginseng in management of diabetes and vascular disease: a Toronto's ginseng clinical testing program. J Ginseng Res 2010;34:264-273.

5. Nam KY. Clinical applications and efficacy of Korean ginseng (Panax ginseng C.A. Meyer). J Ginseng Res 2002;26:111-131.

6. Yuan CS, Wang CZ, Wicks SM, Qi LW. Chemical and pharmacological studies of saponins with a focus on American ginseng. J Ginseng Res 2010;34:160-167.

7. Cho DH, Park KJ, Yu YH, Ohh SH, Lee HS. Root-rot development of 2-year old ginseng (Panax ginseng C.A. Meyer) caused by Cylindrocarpon destructans (Zinssm.) Scholten in the continuous cultivation filed. Korean J Ginseng Sci 1995;19:175-180.

8. De Bary A. Hofmeister's handbook of physiological botany. Vol. 2. Amsterdam: Leipzig, 1866.
9. Sturz AV, Nowak J. Endophytic communities of rhizobacteria and the strategies required to create yield enhancing associations with crops. Appl Soil Ecol 2000;15:183-190.

10. Wilson D. Endophytes: the evolution of a term, and clarification of its use and definition. Oikos 1995;73:274-276.

11. Saikkonen K, Faeth SH, Helander M, Sullivan TJ. Fungal endophytes: a continuum of interactions with host plants. Annu Rev Ecol Syst 1998;29:319-343.

12. Schardl CL, Clay K. Evolution of mutualistic endophytes from plant pathogens. In: Carrol G. The mycota. V. Plant relationships, part B. Berlin: Springer, 2007. p.221-238.

13. Schulz B, Boyle C. The endophytic continuum. Mycol Res 2005;109(Pt 6):661-686.

14. Li TY, Zeng HL, Ping Y, Lin H, Fan XL, Guo ZG, Zhang CF. Construction of a stable expression vector for Leifsonia xyli subsp. cynodontis and its application in studying the effect of the bacterium as an endophytic bacterium in rice. FEMS Microbiol Lett 2007;267:176-183.

15. Shiva P, Pental ND, Bhalla-Sarin N. Regeneration of pigeonpea (Cajanus cajan) from cotyledonary node via multiple shoot formation. Plant Cell Rep 1994;13:623627.

16. Arnold AE, Lutzoni F. Diversity and host range of foliar fungal endophytes: are tropical leaves biodiversity hotspots? Ecology 2007;88:541-549.

17. Dreyfuss MM, Chapela IH. Potential of fungi in the discovery of novel, low molecular weight pharmaceuticals. In: Gullo VP. The discovery of natural products with therapeutic potential. Boston: Butterworth-Heinemann, 1994. p.49-80.

18. Rodriguez R, Redman R. More than 400 million years of evolution and some plants still can't make it on their own: plant stress tolerance via fungal symbiosis. J Exp Bot 2008;59:1109-1114.

19. Rodriguez RJ, White JF Jr, Arnold AE, Redman RS. Fungal endophytes: diversity and functional roles. New Phytol 2009;182:314-330.

20. Boyle C, Gotz M, Dammann-Tugend U, Schulz B. Endophyte-host interactions. III. Local vs. systemic colonization. Symbiosis 2001;31:259-281.

21 . Faeth SH. Are endophytic fungi defensive plant mutualists? Oikos 2002;98:25-36.

22. Brundrett MC. Understanding the roles of multifunctional mycorrhizal and endophytic fungi. In: Schulz BJ, Boyle CJ, Sieber TN, eds. Microbial root endophytes. Berlin: Springer, 2006. p.107-132.

23. Kumar DS, Hyde KD. Biodiversity and tissue-recurrence of endophytic fungi in Tripterygium wilfordii. Fungal Divers 2004;17:69-90.

24. Huang WY, Cai YZ, Hyde KD, Corke H, Sun M. Biodi- 
versity of endophytic fungi associated with 29 traditional Chinese medicinal plants. Fungal Divers 2008;33:61-75.

25. Karthikeyan B, Jaleel CA, Lakshmanan GM, Deiveekasundaram M. Studies on rhizosphere microbial diversity of some commercially important medicinal plants. Colloids Surf B Biointerfaces 2008;62:143-145.

26. Weber RW, Kappe R, Paululat T, Mosker E, Anke H. Anti-Candida metabolites from endophytic fungi. Phytochemistry 2007;68:886-892.

27. Stierle A, Strobel G, Stierle D. Taxol and taxane production by Taxomyces andreanae, an endophytic fungus of Pacific yew. Science 1993;260:214-216.

28. Zhang Q, Kang X, Zhao W. Antiangiogenic effect of lowdose cyclophosphamide combined with ginsenoside $\mathrm{Rg}_{3}$ on Lewis lung carcinoma. Biochem Biophys Res Commun 2006;342:824-828.

29. Tejesvi MV, Kini KR, Prakash HS, Subbiah V, Shetty HS. Genetic diversity and antifungal activity of species of Pestalotiopsis isolated as endophytes from medicinal plants. Fungal Divers 2007;24:37-54.

30. Mitchell AM, Strobel GA, Hess WM, Vargas PN, Ezra D. Muscodor crispans, a novel endophyte from Ananas ananassoides in the Bolivian Amazon. Fungal Diviers 2008;31:37-43.

31. Aly AH, Debbab A, Kjer J, Proksch P. Fungal endophytes from higher plants: a profilic source of phytochemicals and other bioactive natural products. Fungal Divers 2010;41:1-16.

32. Xu LL, Han T, Wu JZ, Zhang QY, Zhang H, Huang BK, Rahman K, Qin LP. Comparative research of chemical constituents, antifungal and antitumor properties of ether extracts of Panax ginseng and its endophytic fungus. Phytomedicine 2009;16:609-616.

33. Xing X, Guo S, Fu J. Biodiversity and distribution of endophytic fungi associated with Panax quinquefolium L. cultivated in a forest reserve. Symbiosis 2010;51:161166.

34. Dang L, Li G, Yang Z, Luo S, Zheng X, Zhang K. Chemical constituents from the endophytic fungus Trichoderma ovalisporum isolated from Panax notoginseng. Ann Microbiol 2010;60:317-320.

35. White TJ, Bruns T, Lee S, Taylor JW. Amplification and direct sequencing of fungal genes for phylogenetics. In: Innis M, Gelfand DH, Sninsky JJ, White TJ. PCR protocols: a guide to methods and applications. San Diego: Academic Press, 1990. p.315-322.

36. Hata K, Futai K. Endophytic fungi associated with healthy pine needles and needles infested by the pine needle gall midge, Thecodiplosis japonensis. Can J Bot 1995;73:384390 .
37. Felsenstein J. Confidence limits on phylogenies: an approach using the bootstrap. Evolution 1985;39:783-791.

38. Tamura K, Dudley J, Nei M, Kumar S. MEGA4: Molecular Evolutionary Genetics Analysis (MEGA) software version 4.0. Mol Biol Evol 2007;24:1596-1599.

39. Nei M, Kumar S. Molecular evolution and phylogenetics. New York: Oxford University Press, 2000.

40. Gotz M, Nirenberg H, Krause S, Wolters H, Draeger S, Buchner A, Lottmann J, Berg G, Smalla K. Fungal endophytes in potato roots studied by traditional isolation and cultivation-independent DNA-based methods. FEMS Microbiol Ecol 2006;58:404-413.

41. Suryanarayanan TS, Wittlinger SK, Faeth SH. Endophytic fungi associated with cacti in Arizona. Mycol Res 2005;109(Pt 5):635-639.

42. Taylor JE, Hyde KD, Jones EB. Endophytic fungi associated with the temperate palm, Trachycarpus fortunei, within and outside its natural geographic range. New Phytol 1999;142:335-346.

43. Kumaresan V, Suryanarayanan TS. Occurrence and distribution of endophytic fungi in a mangrove community. Mycol Res 2001;105:1388-1391.

44. Ananda K, Sridhar KR. Diversity of endophytic fungi in the roots of mangrove species on the west coast of India. Can J Microbiol 2002;48:871-878.

45. Zhao YJ, Wang YP, Shao D, Yang JS, Liu D. Autotoxicity of Panax quinquefolium L. Allelophathy J 2005;15:67-74.

46. He CN, Gao WW, Yang JX, Bi W, Zhang XS, Zhao YJ. Identification of autotoxic compounds from fibrous roots of Panax quinquefolium L. Plant Soil 2009;318:63-72.

47. Saunders M, Kohn LM. Evidence for alteration of fungal endophyte community assembly by host defense compounds. New Phytol 2009;182:229-238.

48. Fisher PJ, Petrini O. A comparative study of fungal endophytes in xylem and bark of Alnus species in England and Switzerland. Mycol Res 1990;94:313-319.

49. Frohlich J, Hyde KD, Petrini O. Endophytic fungi associated with palms. Mycol Res 2000;104:1202-1212.

50. Ganley RJ, Newcombe G. Fungal endophytes in seeds and needles of Pinus monticola. Mycol Res 2006;110(Pt 3):318-327.

51. Aveskamp MM, De Gruyter J, Crous PW. Biology and recent developments in the systematics of Phoma, a complex genus of major quarantine significance. Fungal Divers 2008;31:1-18.

52. Macia-Vicente JG, Jansson HB, Abdullah SK, Descals E, Salinas J, Lopez-Llorca LV. Fungal root endophytes from natural vegetation in Mediterranean environments with special reference to Fusarium spp. FEMS Microbiol Ecol 2008;64:90-105. 
53. Frohlich J, Hyde KD, Petrini O. Endophytic fungi associated with palms. Mycol Res 2000;104:1202-1212.

54. Sieber TN. Fungal root endophytes. In: Waisel Y, Eshel A, Kafkafi U, eds. Plant roots: the hidden half. New York: Marcel Dekker, 2002. p.887-917.

55. Venuto BC, Smith RR, Grau CR. Virulence, legume host specificity, and genetic relatedness of isolates of Fusarium oxysporum from red clover. Plant Dis 1995;79:406-410.

56. Summerell BA, Leslie JF. Genetic diversity and population structure of plant pathogenic species in the genus
Fusarium. In: Gillings M, Holmes AJ, eds. Plant microbiology. Oxford: Bios Science Publishers, 2004. p.207-223.

57. Verma VC, Gond SK, Kumar A, Kharwar RN, Strobel G. The endophytic mycoflora of bark, leaf, and stem tissues of Azadirachta indica A. Juss (neem) from Varanasi (India). Microb Ecol 2007;54:119-125.

58. Gorenz AM, Walker JC, Larson RH. Morphology and taxonomy of the onion pink-root fungus. Phytopathology 1948;38:831-840. 